Innovative Applications for Presenting Heritage in the Visual Arts Medium: A Case Study of the Omani Legends and Stories Exhibition

\author{
Nada Al-Ajmi \\ Assistant Professor \\ Department of English \\ College of Arts \& Social Sciences \\ Sultan Qaboos University \\ nadar@squ.edu.om
}




\title{
Innovative Applications for Presenting Heritage in the Visual Arts Medium: A Case Study of the Omani Legends and Stories Exhibition
}

\author{
Nada Al-Ajmi
}

\begin{abstract}
In transforming the folk tale into a visual medium, contemporary artists have illuminated the remarkable flexibility of this cultural heritage. The Omani Legends and Stories exhibition held in 2012 featured forty-two contemporary artists inspired to re-interpret folk tales that encapsulated beliefs and values relevant in present-day Oman. Several years later, qualitative interviews were conducted with seven of the artists whose work depicted stories focused on representations of women. Together with some analysis of academic writing in the field of traditional tales, this study also garnered artists' viewpoints as expressed in their art works and revealed in discussions with the artists themselves. It was found that there is continuity in the cultural values and beliefs across generations, that folk tales are still being passed on and that women were represented in them in an intriguingly positive light. The continuing observance of cultural restrictions practiced on women was not supported in either the folk tales or the artists' own viewpoints. The example provided by Oman's visual arts industry may inspire similar initiatives in other societies and further research on possible linkages between different art mediums that could be harnessed to further the betterment of women's socio-cultural situation.
\end{abstract}

Keywords: Folktales, Contemporary Art, Omani Legends, Women, Omani Culture.

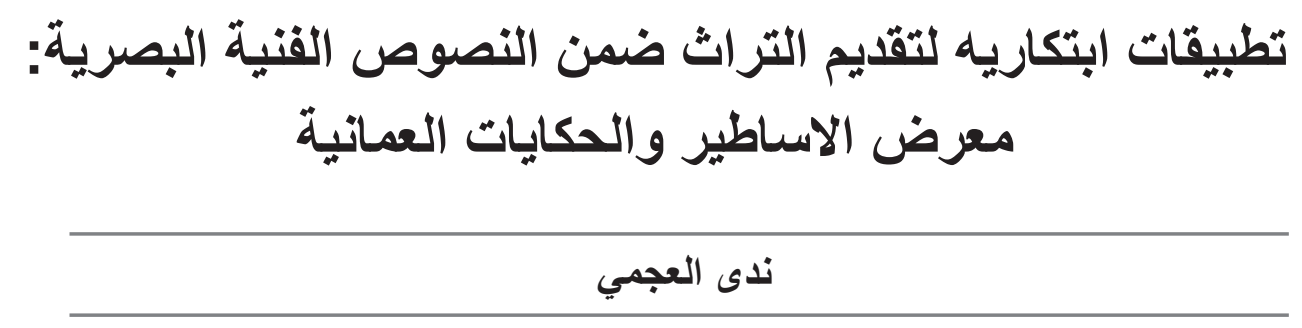

مستخلص

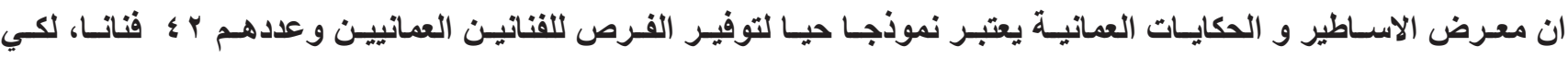

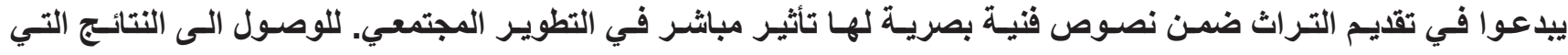

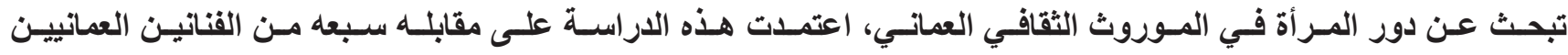

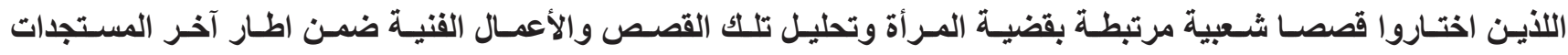

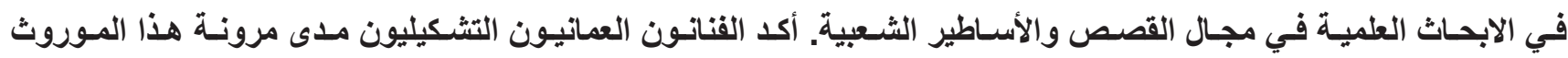

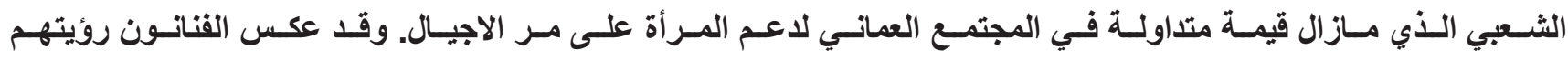

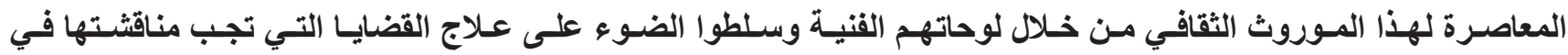

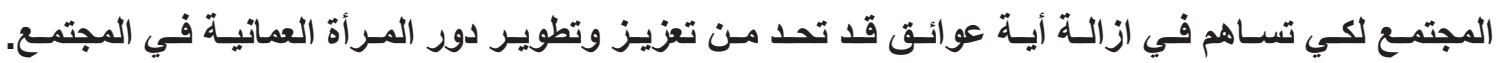

كلمات مفتاحية: المرأة، القصص الثعبية العمانية، الأساطير العمانية، معرض الأساطير والحكايات، الفنانين العمانيين. 


\section{Introduction}

Folktales are an enduring form of heritage, traditionally passed on in oral form, then written down and now visually interpreted by contemporary artists in art works printed on flags and shown at the Omani Legends and Stories exhibition (OLS). ${ }^{1}$ When I spoke with Mariam AlZadjali, head of the Omani Society for Fine Arts, on 17 August, 2015, she explained that in this exploration of linkages between Oman's artistic and cultural history:

"We wanted to celebrate the cultural aspect of these folk tales while making them even more accessible to today's generation. Furthermore, many of the practices in the folk tales are still evident today as they are part of Oman's identity".

As detailed in the next section, the exhibition comprised over forty artists re-telling a wide range of tales through a visual lens. In this paper, I will focus on how representation of women in Omani folk tales has been translated into works of contemporary art in the OLS exhibition. Qualitative interviews were held with seven artists selected because their art works depicted folk tales featuring women. The analysis of art works from the exhibition and their relationship to the folk tales that inspired them is therefore informed by the outcome of these discussions with these artists.

Before examining the exhibition in terms of what insights it provides as regards gradually evolving social changes for women occurring within the framework of a traditional cultural heritage, I will provide some background information about the OLS exhibition, as well as some academic thinking around the artist-folktale dynamic.

\section{Background and Concepts}

In his research on the importance of the use of folklore in the classroom, Alan Dundes notes that folk tales create a, "forum for [the] consideration of 'real' life" (2007:57). He explains important aspects of the nature of this oral tradition, including that folklore does not have one correct version but rather it evolves through the passage of time. One of Dundes's methods is to select an aspect of folklore and ask each student in his classroom research to tell his or her own version of it, thus highlighting the diversity within these versions despite their underlying uniformity (Dundes, 2007: 57-58).

A parallel between Dundes's experiment (2007) and the OLS exhibition (2012) can be drawn. While Dundes's assertions pertain to folktales and the exhibition's title includes legends, this paper will use the terms folktales to encompass both. Alegend is defined as "a story coming down from the past; [especially] one popularly regarded as historical although not verifiable" (Legend, 2012) whereas a folktale can be described as "a characteristically anonymous, timeless, and placeless tale circulated orally among a people" (Folktale, 2012). Both legends and folktales encompass well-known narratives that are part of a culture. Furthermore, for the context of this exhibition and paper the two fields converge and could fall under the umbrella of traditional Omani tales. Hence, the term folktales in this paper refers to Omani folktales and legends such as those used in the work of the artists. The OLS exhibition was initiated by the Omani Society for Fine Arts in cooperation with the British Council and the Delfina Foundation to artistically express this aspect of Oman's heritage. Prior to the exhibition forty-two artists worked in collaboration with Dillwyn Smith, an award winning artist and lecturer, to develop a personal narrative through looking back at the folktales and the legends retold in their families. The artists visited sites where all the legends and folk tales are thought to have originated some six-thousand years ago. Like Dundes's students, the Omani artists each created their own conceptions of the stories though their art work. Despite their breadth, collectively all of the pieces captured and communicated the same, "incredibly beautiful and sometimes scary history of a seafaring nation", as Paul Doubleday, Director 
of the British Council in Oman, explains in his introduction to the exhibition's catalogue which comprises photographs of the art works together with a summary of the folk tales on which they are based (Ahmed \& Sadiq, 2012).

A similar example of re-imagining folk tales from a different perspective can be found in Sahar AlMouji's (2008) writing on folk tales in Egypt, where folk tales are considered to be historical treasure; it is perhaps understandable that social mores, like patriarchy, are regarded as absolutes. In her research Al-Mouji highlights the significance of a project in 1998 to re-write traditional Egyptian folk tales and stories from One Thousand and One Nights from a female perspective so as to give a voice to the women and to reflect a broader perspective of society (Al-Mouji, 2008: 216- 217). Hasan El-Shamy's rationale in analyzing and presenting the folktales of the Arab world in his work Tales Arab Women Tell, also highlights the importance of the female voice in a folk narrative context. (El-Shamy, 1999). While the OLS exhibition included both male and female artists' narrative voices, the selected artists for this case study, in the process of reimagining the folktales from a different perspective, chose the subject of their narrative voice to be women centered, folktale inspired artwork.

To add another layer of complexity, the artists' individual interpretation of the folk tales brings to mind leading researcher and collector of Omani folktales, Aisha Al-Darmaki's ${ }^{2}$ conception of narrative voice in oral traditions (Al-Darmaki, personal communication, September 2, 2015). AlDarmaki asserts that folktales, due to their oral narrative form, are faced with many challenges pertaining to the narrator's effect on narration and influence over adding or withholding informationwhether as a conscious or an unconscious process. When transposing concepts from an oral to a visual medium, the narrator's impact and the dynamics between the artist, characters and storyline of the folk tale are further complicated by the artist's identity and perspective. The artist now plays the role of the narrator through a visual medium. At the same time, the changeability of these folktales from oral to visual gives them power, as Rick Altman says, "...narrative gains much of its power from its ability to change form easily and repeatedly." (2008: 1).

The matter of artist authenticity also needs to be addressed. Painter and art theorist Wassily Kandinsky's (1982) conception of art considers every work of art to be, "the child of its time [and] the mother of our emotions... every period of culture produces its own art, which can never be repeated. Any attempt to give new life to the artistic principles of the past can at best only result in a work of art that resembles a still born child" (Kandinsky \& Lindsay, 1982: 83). Kandinsky's viewpoint seems valid in relation to Omani artists interpreting folk tales when creating their own paintings, however, the artists were not attempting to reproduce folk tales per se or use, "forms of bygone periods" (Kandinsky et al., 1982: 83). Rather, while capturing the essence of folk tales and being inspired by them, the artists created unique art works in the present day and imbued with modern feelings, capturing Altman's assertion that "applied to each new mode of communication, narrative has remained ever present, ever up to date." (2008: 1). Fadwa Abdel Rahman's (2008) assertions about Michael Cunningham's film, The Hour, based on the Virginia Woolf's novel are relevant to this point in that she argues that each medium should be considered as an independent artistic production of its own although it may still be beneficial to critically compare work from two different mediums (Abdel Rahman, 2008: 150). It is also important to note that while the artists keep the story alive and maintain its essence, when they transfer the folktale narratives to another medium, they don't necessarily keep the exact same story. Yet, this does not contradict Altman's explanation that:

However different the media that serve as a given story's vehicles-however distinct the oral, 
written, illustrated, or film versions of a particular narrative-we readily recognize a story's ability to be translated into different forms and yet somehow to remain the "same" story. Clearly, narrative exists independently of the media that give it concrete form. (Altman, 2008: 1).

The artists did not loose the story in changing the medium, but consciously aimed to capture the essence of the folktales to create a unique work of art in the present day imbued with contemporary sentiment.

\section{Interview Methodology}

Informal interviews were conducted with seven of the artists whose work depicted stories focused on representations of women. Guiding questions (found in Appendix B) were used to frame the interview to ensure that relevant topics were covered. However, I aimed to keep the tone of the interviews conversational to allow the artists some freedom to express their views and insights on their work. I revised all interview notes and highlighted the most relevant portions to convey in the below sections for each artist respectively. The interviews were also considered holistically to note reoccurring themes and rationales. The interviews also helped inform my analysis of the artwork. While this paper is by no means a comprehensive survey of Omani contemporary artists or the influence of folktales on Omani art, it provides insights into the ideas behind the OLS exhibition and aims to spur thought for further research in the relationship between cultural heritage and contemporary media art.

\section{OLS Exhibition}

\section{Issa Al-Mafrigi}

Moving on to explore the OLS exhibition, we begin with the artist Issa Al-Mafrigi who I interviewed on 2 September, 2015 at a coffee shop in Opera Galleria. Al-Mafrigi reflected on the story of a poor woman who received a fish as a gift from a fisherman and how her life improved after she sold a golden ring she had found in the fish's belly. Al-Mafrigi explained that women have always represented sustenance and symbolized the acquisition of income in both traditional Omani tales and in the beliefs of Omani society. For example, a commonly held belief is that when a man gets married his income will increase because he will be blessed by the comfortable life his wife will make possible for him. However, the woman does not just bring blessings for her husband but is also better able to provide for herself. This theme is reflected in the folk tale of the woman and the fish which highlights how the woman, at a difficult time in her life, secured her financial future by using her wisdom in not choosing to wear the ring but to sell it in order to generate an income. Al-Mafrigi's painting (see Appendix A, figure 1$)^{3}$ focuses on the woman and the fish as a symbol of sustenance and livelihood. Al-Mafrigi explained that the fish, facing down and its body painted with designs from traditional Omani rings, symbolizes a strong belief that livelihood and sustenance comes from the Supreme Power of God and that the circular shape of the rings indicates financial ease and a secure livelihood. This idea is reinforced by the matching curved, sliding shape of the woman's scarf reflecting her wisdom in response to finding the ring. Al-Mafrigi pointed out that the design on the woman's scarf was inspired by traditional Omani wooden doors symbolizing home and connecting the notion of the home with the female as refuge and source of good fortune for the entire family. The woman's scarf has Arabic writing in blue, symbolizing the sea and its representation in Omani folk tales as a major source of income for coastal cities. The calligraphy contains words from the folk tale itself that the artist wanted to highlight.

For Al-Mafrigi, art transcends its aesthetic value to become an expression of truths that the artist perceives in his or her society. Al-Mafrigi believes that the concept of promoting equality does not do justice to the status of women in society as it is based on an underlying assumption that 
women are not equal to men, whereas Al-Mafrigi believes that despite differences in the functions they perform, woman and man are equal in status. Through his art work Al-Mafrigi conveys his message, in particular, to the younger generation of the society who he believes have the intellectual capacity and energy to drive the nation forward.

\section{Alia Al-Farsi}

In my meeting with Alia Al-Farsi on 15 August at Alia Gallery she explained that although most of the folk tales are not necessarily based on true stories, "they do reflect the true social and cultural values of our ancestors." For example, the folk tale that Al-Farsi painted (see Appendix A, figure 2 ) highlights the culture of arranged marriages in Omani society. Since it is difficult for a woman to openly voice her wishes on this, one of the most important decisions of her life, instead, the woman in this tale used her wisdom to obtain what she wanted, thus still respecting cultural values. In the tale an Imam had decided his daughter would be married to her cousin and she followed the cultural practice of tossing lemons to her arranged marriage partner except-in accordance with the local custom and as her father watched in disbelief-ten times she threw the lemons to a stranger who was poor. Al-Farsi's painting depicts only half of the woman's face, reflecting her lack of choice but the artist also depicts her strength and wisdom in focusing on the woman's firm gaze and the reflection of the man of her choice in her eyes, despite her sealed lips.

\section{Said Al-Alawi}

On 3 September, 2015 at a coffee shop in Opera Galleria I spoke with Said Al- Alawi about the folk tale he had chosen, which also features the issue of a woman's right to choose her husband and highlights outcomes associated with social restrictions that are still prevalent in some parts of Oman. The artist explained that the consequence is not always that of the woman using her wisdom to find a solution-in some cases the woman will resort to plotting and making cunning decisions. In this particular folk tale, when a woman's family refused to let her marry the man she loved she decided to get married to her neighbor, a widowed man with a young son. She did this in order to break free of her family's restrictions and to be able to meet her beloved when her husband was absent. The new bride then proceeded to plot the removal of her stepson and his' horse, eventually forcing the boy to flee to another kingdom where the king's daughter noticed the boy and they became good friends. Restrictions on women's right to choose a husband did not occur in this locality so when the king selected a day for his daughter's marriage the daughter chose the young man and they lived happily ever after. Al-Alawi remarked that these kinds of social restrictions are discussed in Omani folk tales in order to indicate the importance of establishing a family based on choice and compatibility.

In his painting, therefore, he focuses on the princess's wedding ceremony as a positive model demonstrating the significance of choice in marriage rather than on the woman's resorting to plotting and cunning decisions (see Appendix A, figure 3 ). This is an example of Al-Darmaki's point regarding the importance of narrative voice in oral traditions and the narrator's effect on adding or withholding information. Here, the artist used his narrative voice and personal perspective to highlight certain cultural practices and values he deemed favorable. Yet it is also important to note, as Ibrahim Muhawi explains in his discussion on translating oral style in Palestinian folktales that, "in folktale narration the teller is not involved directly with the audience; the genre stands between them" (Muhawi, 2004: 89). Through this process of change via the narrative voice, the genre becomes a medium through which the artist can express his views. Al-Alawi explained that the color blue around the boy's head reflects his pure intentions which led him with his horse to the loving and caring princess who wears green symbolizing the positive nature of the society in which she lived-a 
society that allowed the princess to choose her own partner and a stranger in her community at that. Choice is what ensured the family's future prosperity and happiness, contrasting with the earlier scene in the story where the stepmother was forced to be cunning in order to evade social restrictions. The painting also depicts a scene from the wedding ceremony in which women and men are dancing together, thus demonstrating that females have always been part of Oman's public life.

Al-Alawi explained that listening to the folk tales his mother would tell him shaped his character and that as a result he highly values female wisdom and regards women as an integral part of society. He recalled several tales, including the woman who did not let her disagreement with her in-laws affect her children's love for them; the tale in which a woman invested the money her husband gave her on buying a cow then selling its products; and the story of the man with seven girls who could sail the seas and generate more income than the man with seven boys. All of these stories, according to Al-Alawi, have enriched his artistic work and influenced his decision to make women one of the central themes in his other work as well, for example, Omani fashion designer, Amal Al-Jamali, has used Al-Alawi's art work in her designs (see Appendix A, figure 4).

\section{Aseelah Al-Alawi}

Another focus of art works in the exhibition was the question of women and beauty. A common cultural belief to this day, the notion of an "envious [or] evil eye" broadly means that success of any kind automatically arouses the fear that someone else may envy or be jealous of one's achievement or physical beauty and should this occur then that success, achievement, happiness, and so on, will be turned against one or be taken away. Aseelah Al-Alawi is one of the younger artists and in our telephone conversation on 7 September, 2015 she explained that her aim in painting the tale she chose (see Appendix A, figure 5 ) is to question the belief that women's beauty is reason enough for her to suffer affliction. In this story a young woman's peerless beauty was the reason people attacked her with their envious eyes until she became severely ill then died. After her death her soul haunted the family's home and for many generations her voice was heard coming from the wall. In her painting, Al-Alawi evokes the girl's matchless beauty in a traditional jewelry head piece that also symbolizes her cultural wealth. Behind her, the sketch of a mosque symbolizes her spiritual values. Overall she is represented as a distinguished woman, endowed not only with physical beauty but also inner moral, cultural and spiritual beauty, which is visually depicted in the sparkling dots all over her face and body. Connecting the the evil eye and the girl's death with her beauty questions the social restrictions placed on women as the evil eye acts as a warning which paints beauty with shame.

\section{Zainab Al-Mabsali}

Zainab Al-Mabsali explored a similar theme in her painting and during our conversation at the coffee shop in Opera Galleria on 9 September, 2015 she re-iterated the story of what befell a girl who left her friend's house at night wearing make-up and looking beautiful. The girl walked past an old man, collapsed soon after and was unable to speak or move her body. Everyone thought she had died and they began moving her to the graveyard until a man who was passing by stopped and told them that she was not dead but in a state of enchantment. No one believed the intelligent man except her mother who put a piece of mercury in her daughter's hand and successfully broke the spell. Al-Mabsali described how audiences reacted when they saw her painting (see Appendix A, figure 6): "They would pause and in astonishment ask me, 'What is the story behind this painting?'" Al-Mabsali is among the younger generation of artists in Oman and she explained that she wanted to convey the strong message behind this folk tale. As much as the enchantment in the story 
symbolically represented control over a womaninstructing her not to reveal her beauty or dress up-Al-Mabsali wanted to show in her art that a woman experiencing such control could well be "living a dead life while she is alive". In the painting the woman is surrounded by darkness and wrapped all over with white cloth and chains. Her head and hair are uncovered symbolizing the woman's active mind questioning the limitations and restrictions forced upon her. The woman has three faces, one that appears calm while in trancelike enchantment yet she is also chained and on the other two faces the mouths are gagged and tears fall from the eyes.

Al-Mabsali is reflecting the dilemma and frustration confronting females who, on the one hand, have been granted new, modern opportunities yet, on the other hand, in some parts of Oman women still experience socio-cultural taboos of the kind described in the folk tales, thus restricting their ability to speak out about such limitations on women. The role of the mother, as a fellow woman, is also prominent in the story; she saves her daughter as she does not want to see her daughter re-live her own life and experience the constraints she faced, generally reflecting the older generation's wishes for younger girls. This artist believes that despite the fact that on the surface a weak image of women is narrated, paradoxically, the tale actually sends a strong message of warning against society placing these restrictions on women.

As Dundes (2007) explains, "even the distortion in a people's self-image can tell the trained observer something about that people's values. Out of all the elements of culture, which ones are singled out for distortion, for special emphasis?" (Dundes,2007: 55) The image of the woman in this tale is distorted to place special emphasis on and to warn against restrictions placed on women. In her research on Iberian and Latin American women's writing, Patricia Odber de Baubeta (2004) argues that many contemporary writers, particularly females, use fairy-tale motifs to deconstruct discourses pertaining to gender and women's identity (Odber de Baubeta, 2004: 132). She concludes that, ironically, writers have adopted aspects of conventional fairy tales in order to write their own unconventional tales. De Baubeta focuses on how this genre becomes an important tool in working against patriarchal social structures (Odber de Baubeta, 2004: 144). Similarly, Al-Mabsali used certain conventional norms and beliefs derived from the traditional folktale to present her unconventional views that question the limitations imposed on women.

\section{Noorah Al-Buloshi}

Another artist who chose a folk tale about the evil or envious eye is Noorah Al-Buloshi. In my telephone conversation with Al-Buloshi on 5 September, 2015 she noted, although the phenomenon is not confined to women, many of the stories, including the one she chose, connect it with women. In the tale, it was as if a woman had put a harmful spell on anyone she looked at. She made her husband unable to walk in the first week of their marriage because she considered that he walked too often. Her actions became so uncontrollable that, against her will, her sons locked her in a room so that she couldn't harm anyone else. Al-Buloshi explained that, "Our folk tales captured one of the common beliefs of our society-the evil eye". Her painting (see Appendix A, figure 7) is of an elliptical red vessel shaped like an eye with a circular eye ball painted in black and within it a masked woman also dressed in black-mimicking the imprisonment of the woman in her own pain as she witnessed the harm she was inflicting on others. The young artist said that she intentionally surrounded the eye shape with a border of pastel green to convey that the woman never intended to harm anyone and the incidents that happened were not because she was a woman, rather that it is society's belief in the phenomenon of the envious or evil eye that needs to be addressed and remedied. Furthermore, she explains that the phenomena of the 'evil eye' in Omani society is not confined to women, although a lot of the stories do connect it to women. 


\section{Hafsa Al-Tamimi}

Artist Hafsa Al-Tamimi offers a different perspective on the notion of the envious/evil eye. During our meeting at a coffee shop at Al-Mawj on 8September, 2015 she stated that her art work provides insight into human relationships though the exploration of human desire and emotions, such as envy. AlTamimi painted the story of a jealous woman's plot against her sister-in-law. Al-Tamimi believes women represented in folk tales and legends were often strong and sometimes harsh as a means of selfdefense in the social environments that they had to survive in. To Al-Tamimi, women living in Oman now with the protections by equal legal rights, education and supportive social structures, owe these sociopolitical advancements to the strong woman of the past struggling to survive life's harsher social conditions. Al-Tamimi explained further that most of the folk tales also reflect the complexity of human desires, like jealousy and envy and how women were protagonists in the exploration of these complexities. As women were circumscribed in their ability to express emotions and desires they would end up either submitting to the restrictions imposed on them, casting them as being a helpless victim or else rebelling against it, thus becoming the evil villain, as it were. In the folk tale depicted in Al-Tamimi's painting (see Appendix A, figure 8), the love and harmony shared by the brother and sister was gradually undermined by the brother's envious wife who eventually convinced her husband to kill his sister. The sister was so kind that she watched over her brother even after her death, evidenced in the tale by her removing dust from her brother's body as she was being buried. Her grave stone turned pure white symbolizing her innocence. For Al-Tamimi, this story warns against the complexity of human desire and human relationships and the story's exaggeration highlights that no matter the strength of a bond between siblings the marital bond is stronger.

In her abstract piece of art, Al-Tamimi painted the shape of a rug to metaphorically suggest events woven together to create our life stories.
The pastel green background symbolizes the superficial calmness of life that we might observe in any family from the outside, although each family faces its own challenges when dealing with the complexities of human desire and human relationships. In the middle of this calming green the main characters of the story lie as three rectangles: taking up the largest space is the jealous wife, painted in red while the husband, keeping himself distant from the truth, is painted in purple and the gray rectangle represents the sister, as victim. Surrounding the edges of the painting are panels with images of eyes representing jealousy, images of the dagger used to stab the sister, as well as various shapes and images in groups of two and three, echoing the complex relationship between each pair of protagonists and the threesome.

\section{Conclusions}

In re-telling aspects of folk tales and re-interpreting them in a visual medium these artists have added both their own and another narrative layer to Oman's cultural heritage. Jack Zipes (1983) describes the process of, "transfiguration of the fairy tale" as the re-telling of the same story, maintaining its features and values yet canceling out some of its negativity by "relativizing" it through different aesthetic and social situations (Zipes, 1983: 178). While Zipes's (1983) transfiguration pertains to fairytales, the concept could describe what the artists are doing with the Omani folk tale. However they are not canceling out any of the negativity, instead they are highlighting the lessons to be learnt from these cultural treasures.

Finally, the OLS exhibition was taken as a case study where folk tales and contemporary Omani artists, as it were, conversed with each other. The artists created original pieces inspired by particular folk tales depicting Oman's collective identity through history. Many of the artists chose folk tales centered on women, ranging from those warning against societal limitations and restrictions placed on women through to stories portraying females dealing with the complexity of human 
relationships. The OLS exhibition highlighted how contemporary artists are able to draw directly from their heritage and culture in order to produce narratives that contribute to the representation of Omani women's identity at the present time.

This case study also points to the potential for looking into the work of other Omani artists whose work is focused on women, beyond this particular exhibition. It is interesting to investigate their depiction of women both in traditional Omani culture as well as contemporary Omani society. It would also be worth looking at whether or not folk culture has effected other Omani artists in a context where there is no exhibition requiring the artist to utilize folktales, indicating a greater prominence of the influence of traditional folktales in Omani art and society.

\section{End Notes}

1- Omani Legends and Stories exhibition held at the Omani Society for Fine Arts, the British Council, Bait Al-Zubair and Bait Al-Baranda (all in Muscat, Oman) $-29^{\text {th }}$ April- $13^{\text {th }}$ May, 2012.

2-Aisha Al-Darmaki presented her paper "Discourses of the Other in Narrative Literature." in Folk Culture and Globalization Challenges Forum, 7-9 November 2012, Kingdom of Bahrain, p.1-33.

3- Permission to use images of the artwork has been taken from the Omani Society for Fine Arts. A document proving written permission to use the images was also given to the author and can be available upon request.

\section{References}

Abdel Rahman, F., (2008), From page to celluloid: Michael Cunningham's The Hours, Alif, 28, 150163.

Ahmed, E., \& Sadiq, H. (Eds.), (2012). Omani legends and stories.,Muscat, MCT, Omani Society for Fine Arts, Diwan of Royal Court.
Altman, R., (2008), A theory of narrative, New York: Columbia University Press.

Al-Mouji, S., (2008), From folk tales to woman's tales, Alif, 28, 216-226.

Dundes, A., \& Simon, J. B.; (2007), The meaning of folklore, Logan, UT: Utah State University Press.

El-Shamy, H., (1999), Tales Arab women tell, Bloomington: Indiana University Press.

Folktale, (2012), In: Merriam-Webster's collegiate(R) dictionary, Springfield, MA: MerriamWebster. Retrieved from https://ezproxy.library. nyu.edu/login?url=http://search.credoreference. com/content/entry/mwcollegiate/folktale/0

Kandinsky, W., \& Lindsay, K. C., (1982), Kandinsky: Complete writings on art, Vergo, P. (Ed.), Boston, MA: G.K. Hall.

Legend, (2012), In: Merriam-Webster's collegiate(R) dictionary, Springfield, MA: Merriam-Webster. Retrieved from: https:// ezproxy.library.nyu.edu/login?url=http:// search.credoreference.com/content/entry/ mwcollegiate/legend/0

Muhawi, I., (2004), On Translating Oral Style in Palestinian Folktales, In: Faiq, S., Cultural Encounters in Translation from Arabic, First edition, Clevedon, U.K.: Multilingual Matters, 75-90.

Odber de Baubeta, P. A., (2004), The fairy-tale intertext in Iberian and Latin American women's writings, In: Haase, D. ( Ed.), Fairy tales and feminism: New approaches, Detroit, MI: Wayne State University Press, 129-147.

Zipes, J., (1983), Fairy tales and the art of subversion, New York, NY: Wildman Press. 
Appendix A

Art Work from the Omani Legends and Stories Exhibition

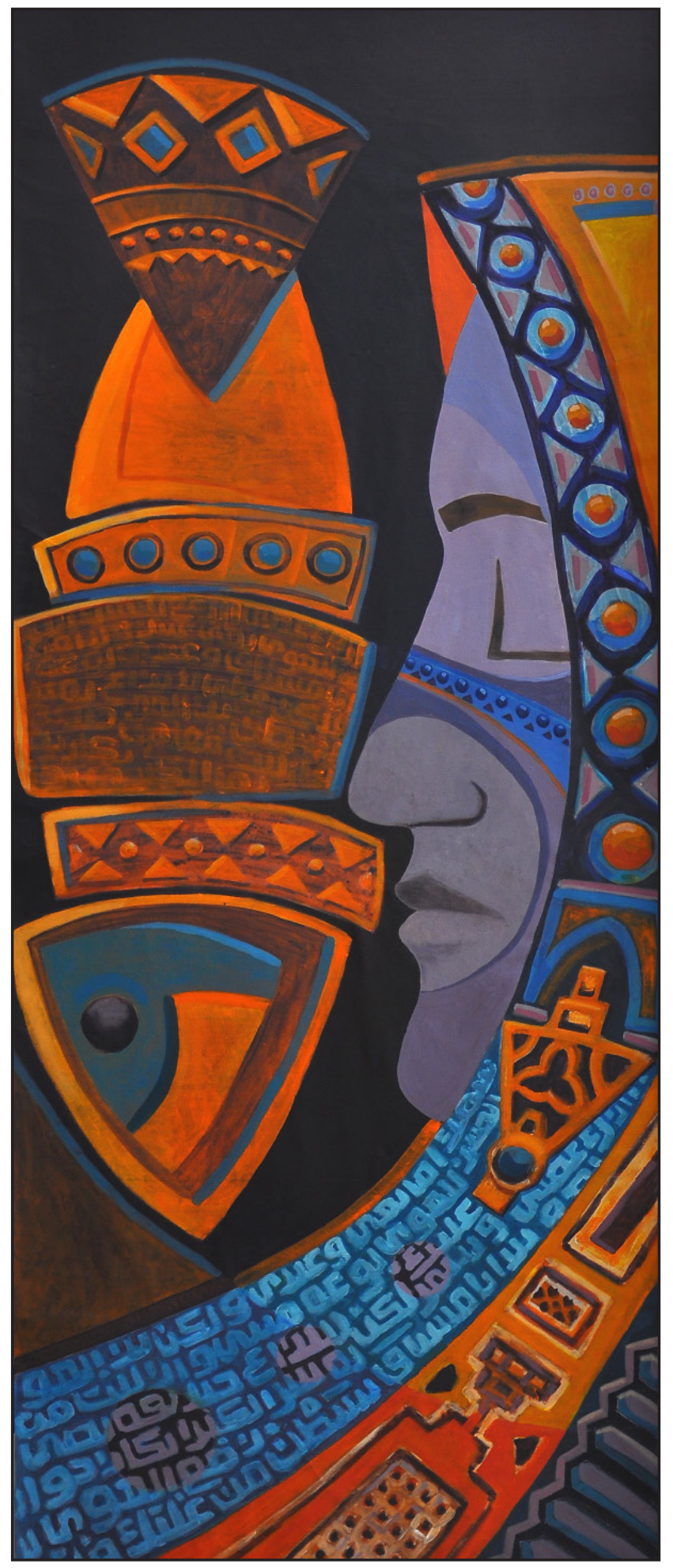

Figure 1

Issa Al-Mafrigi

Untitled

Acrylic on canvas

$106 \times 41$ inches

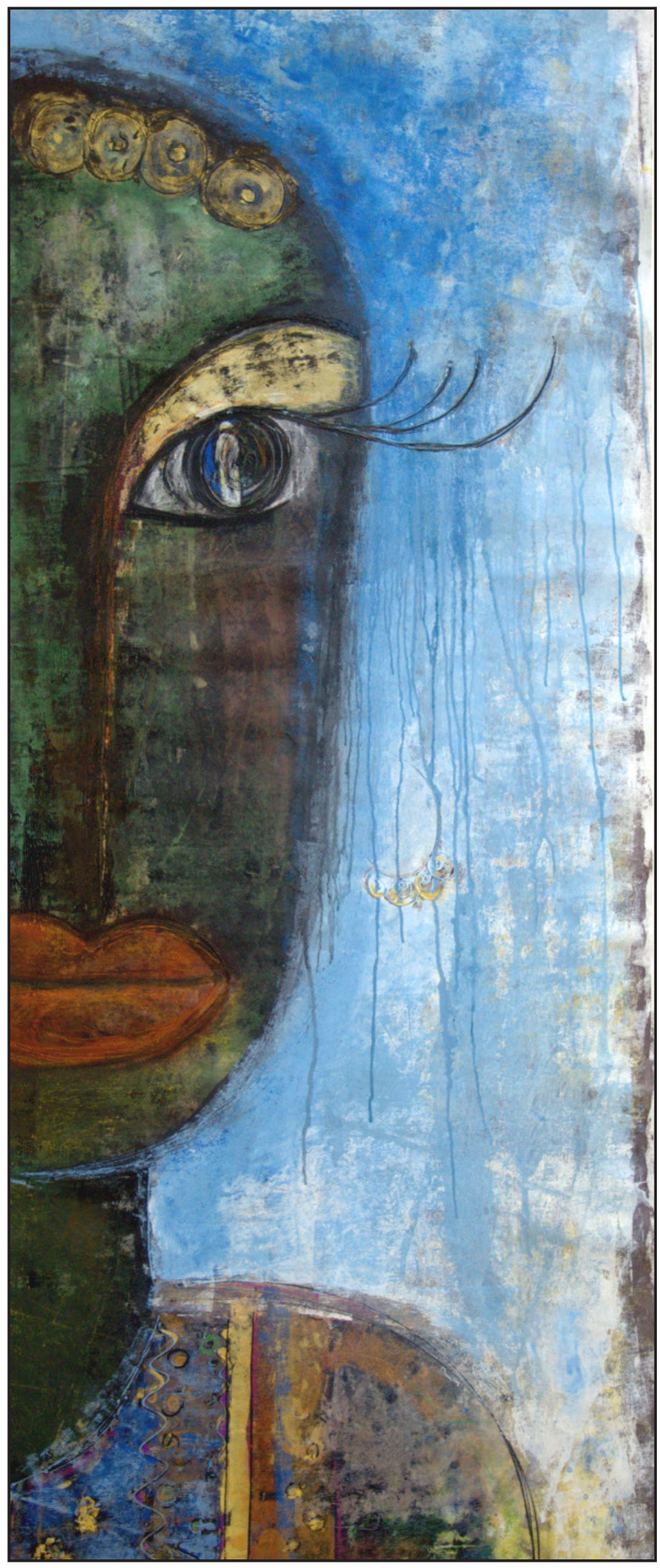

Figure 2

Alia Al-Farsi,

Untitled

Acrylic on canvas

$106 \times 41$ inches 


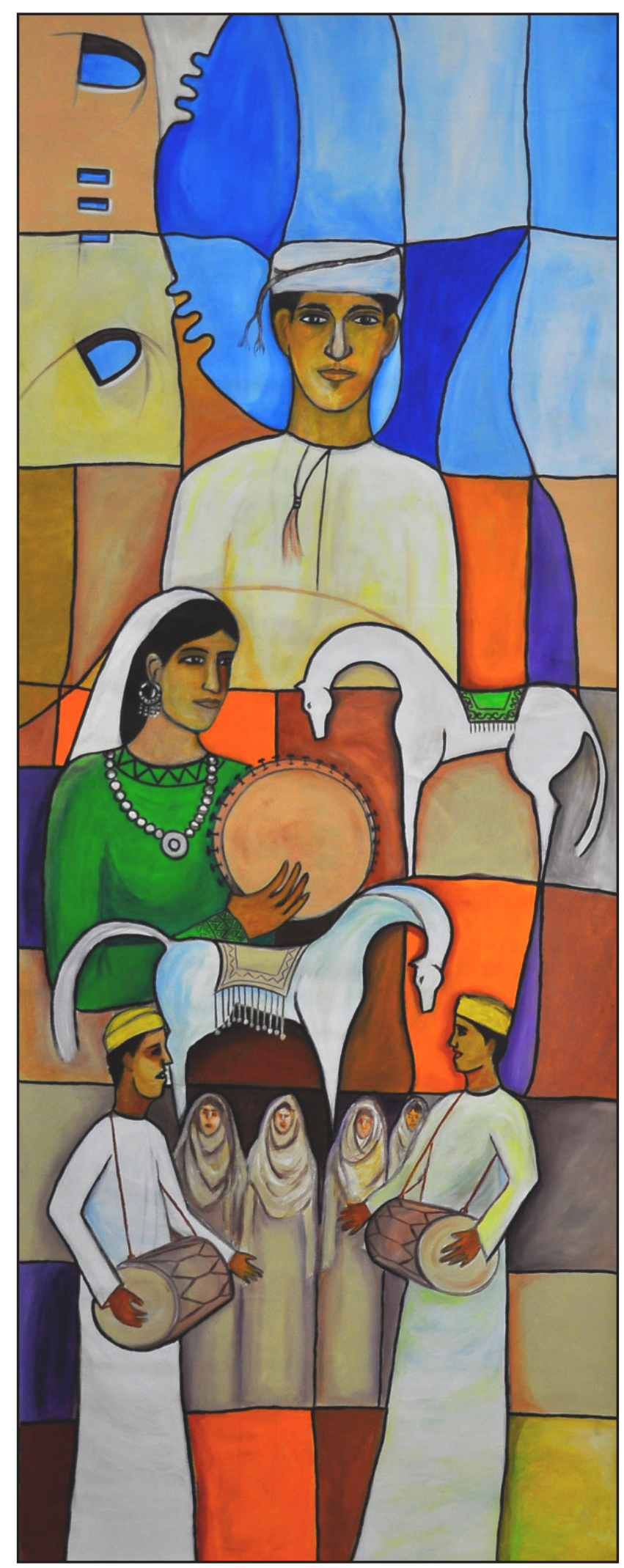

Figure 3

Said Al-Alawi

Untitled

Acrylic on canvas

$106 \times 41$ inches 


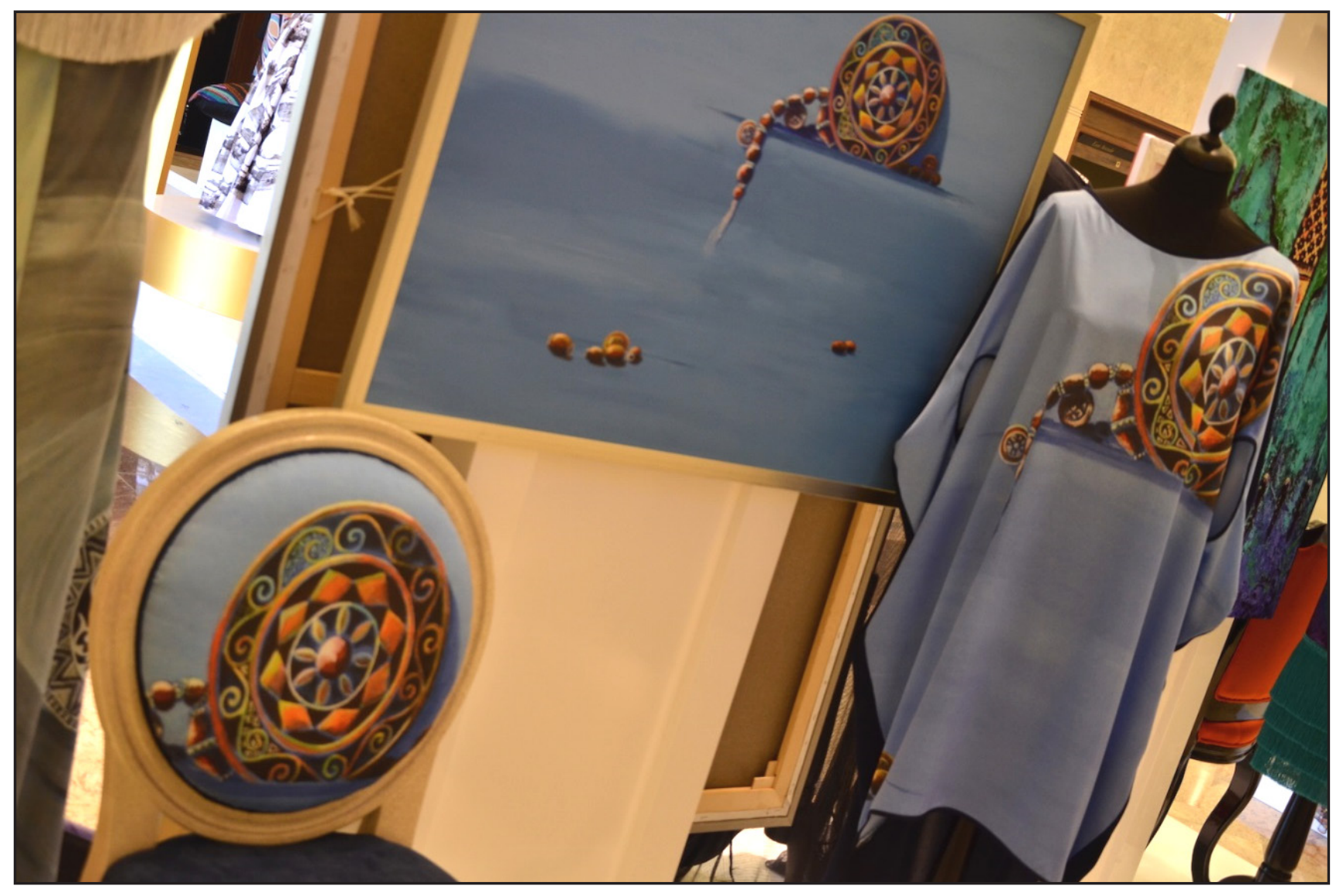

Figure 4

Said Al-Alawi 


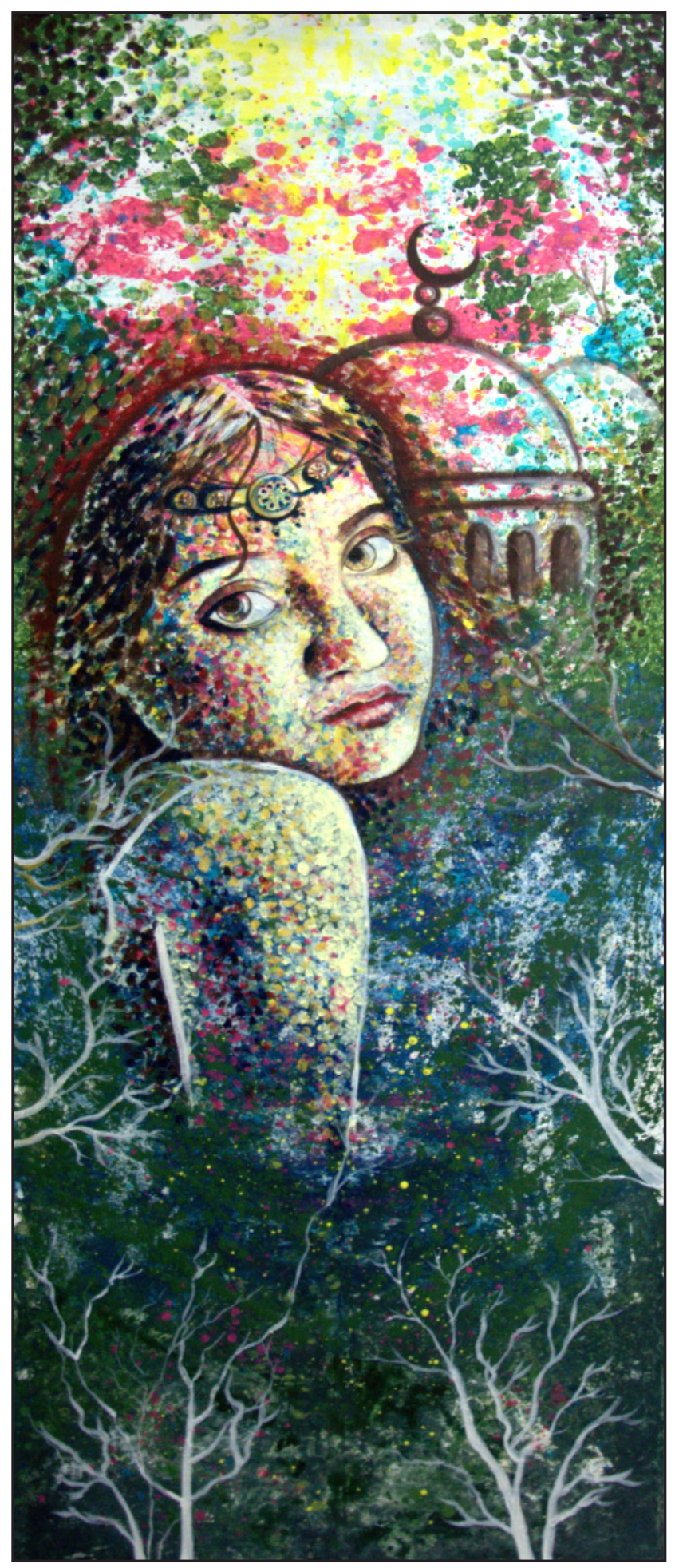

Figure 5

Aseelah Al-Alawi

Untitled

Acrylic on canvas

$106 \times 41$ inches

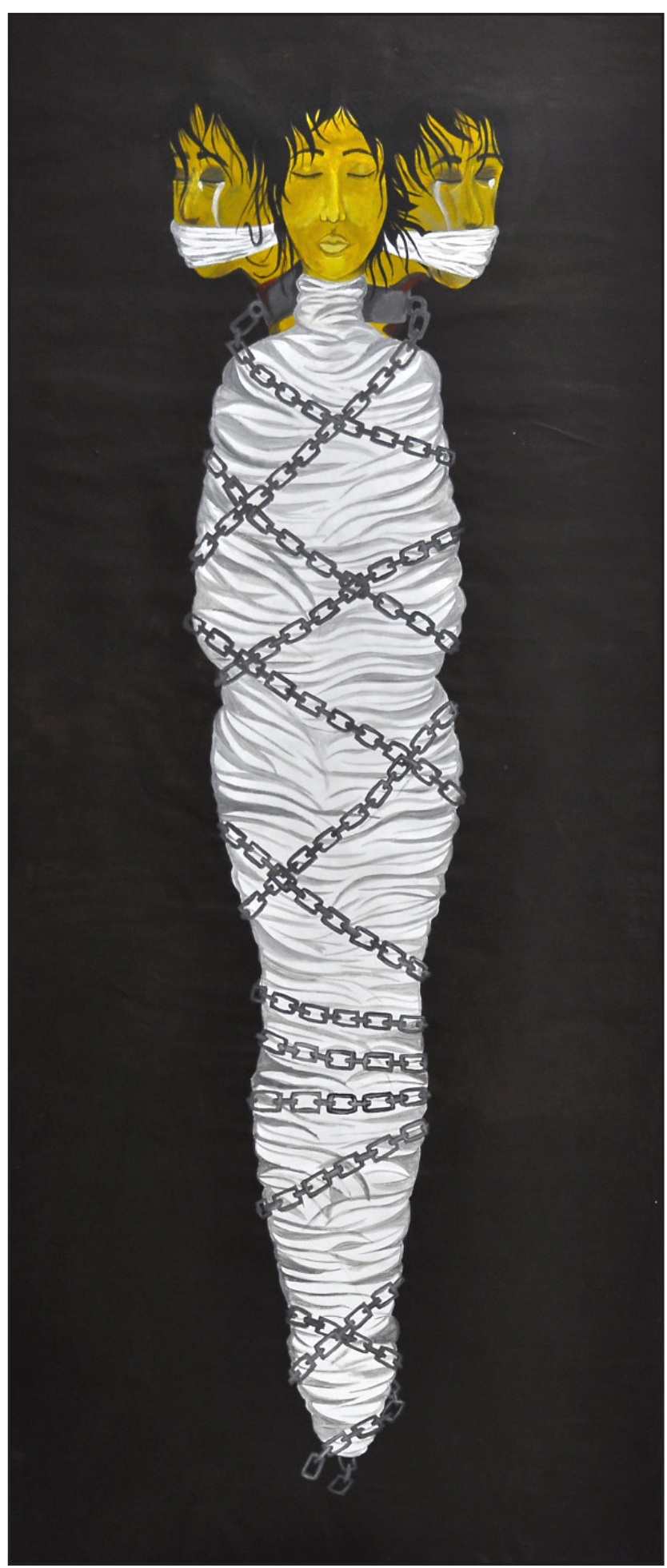

Figure 6

Zainab Al-Mabsali

Untitled

Acrylic on canvas

106x 41 inches 


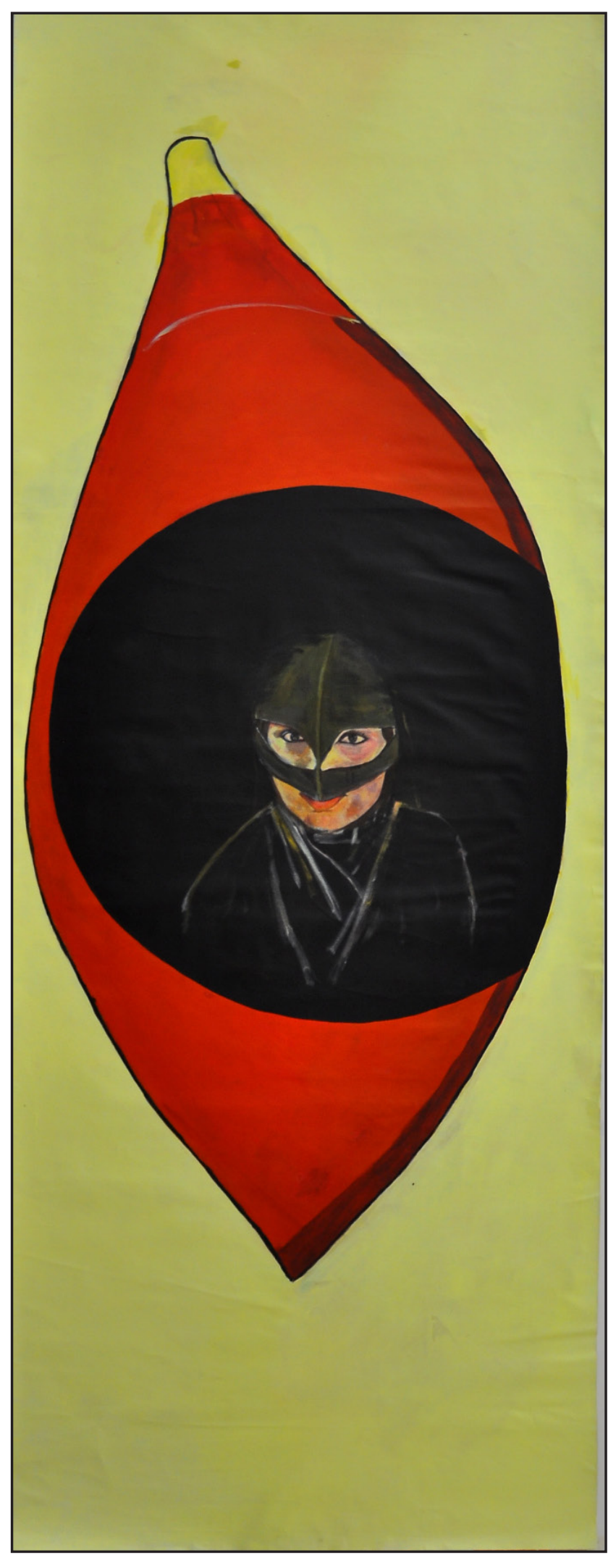

Figure 7

Noorah Al-Buloshi

Untitled

Acrylic on canvas

$106 \times 41$ inches

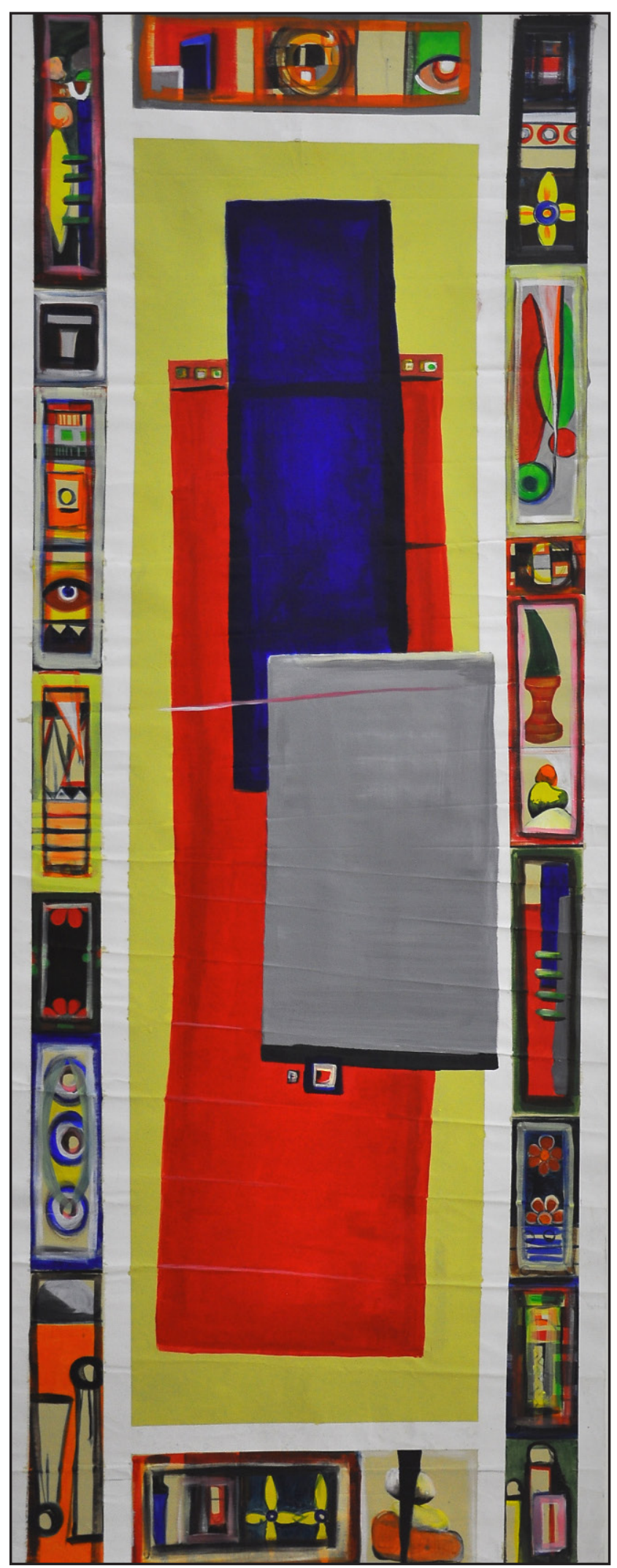

Figure 8

Hafsa Al-Tamimi

Untitled

Acrylic on canvas

106x 41 inches 


\section{Appendix B}

\section{Questions for Discussion for Qualitative Interviews}

General questions pertaining to the artist and his or her style-followed up by the questions, "How do you do this?" and "Can you please provide an example(s)? :

1. How do you describe your style to other people?

2. Why did you decide to become an artist?

3. Has your style changed and evolved over time?

4. What kind of work or aspect of your work do you enjoy doing the most?

5. What do you hope to achieve?

Questions on links between the artist, their work and Omani women and Omani folk tales:

1. What memorable responses have you had to your work?

2. Do you do any research before beginning a piece or a series?

3. What inspires you? (Prompt: culture, heritage, older arts?)

4. Do folk tales inspire your work in any way-directly or indirectly?

5. What themes do you pursue?

6. Do you have a particular message to convey in your work?

7. Do you aim to raise a significant social question through your work [prompt: youth or women] and do you think you have succeeded?

8. Does any of your work bridge the gap between old Omani traditions and today's generation? 